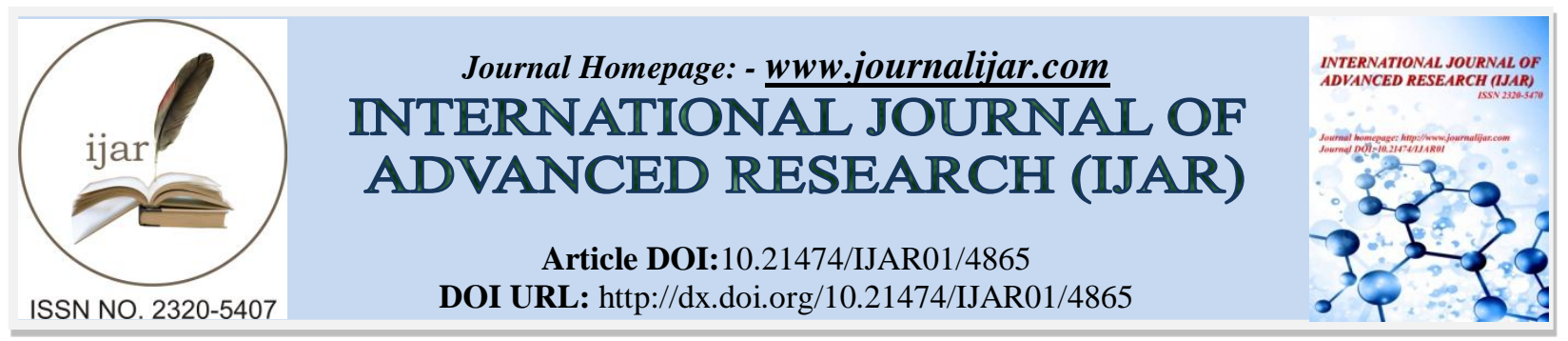

RESEARCH ARTICLE

\title{
ISOLATION AND IDENTIFICATION OF BIOSURFACTANT PRODUCING CHROMATE RESISTANT BACTERIA ISOLATED FROM CHROMIUM CONTAMINATED SITE.
}

Tuhina Verma.

Department of Microbiology Dr RML Avadh University, Faizabad, 224 001, India.

\section{Manuscript Info}

Manuscript History

Received: 16 May 2017

Final Accepted: 18 June 2017

Published: July 2017

Key words:-

Chromate, Bioremediation,

Biosurfactant, Pseudomonas aeruginosa,

Bacillus cereus.

\section{Abstract}

The occurrence of chromate tolerant and biosurfactant producing bacteria with an ability to bioremediate $\mathrm{Cr}(\mathrm{VI})$ through bioreduction was investigated in the soil of waste dumping site of battery manufacturing industry. Two bacterial strains TB9 and TB10 showed high $\mathrm{Cr}$ (VI) MIC values of 1350 and $1400 \mu \mathrm{g} / \mathrm{ml}$, respectively, and also reduced $83 \%$ and $90.0 \%$ of chromate after $20 \mathrm{~h}$ of growth. Interestingly, both the strains were capable to produce biosurfactant in significant amount which was confirmed by methylene blue plate assay, blood hemolysis test, emulsification test and oil displacement activity. The TB9 strain showed highest emulsification index $\left(\mathrm{E}_{24}\right)$ after 24 hours of incubation for sunflower oil $(74 \pm 1.60)$ followed by kerosene $(72 \pm 0.5)$ and olive oil $(65 \pm 0.3)$, whereas, strain TB10 showed highest $\mathrm{E}_{24}$ value for olive oil $(74 \pm 1.2)$ followed by sunflower oil $(70 \pm 0.29)$ and kerosene $(68 \pm 0.19)$ after the same period of exposure. Results for oil spreading test of the kerosene oil revealed that TB9 and TB10 caused the spreading of the oil at the rate of 6 and 5 minutes with a diameter of $2.7 \mathrm{~cm}$ and $3.3 \mathrm{~cm}$, respectively. Based on the results of concomitant biosurfactant production efficiency and chromate reduction potential, strains TB9 and TB10 seems to be most efficient strains that can be potentially be used for $\mathrm{Cr}$ (VI) bioremediation and were identified as Pseudomonas aeruginosa and Bacillus cereus, respectively.

Copy Right, IJAR, 2017,. All rights reserved.

\section{Introduction:-}

The discharge of chromium in the environment through the industrial wastes has become a subject of great concern due to its higher toxicity and non-biodegradable nature. The waste discharged from the battery manufacturing industries contains various chemicals including chromium sulfate in large amount which is ultimately released into the cultivable lands and nearby water bodies beyond the permissible limit (Rehman et al., 2008). The predominant forms of chromium present in environment are the trivalent [ $\mathrm{Cr}(\mathrm{III})]$ and hexavalent chromium [Cr(VI), chromate]. However, $\mathrm{Cr}$ (III) is immobile in nature and acts as a micronutrient in trace amounts, whereas $\mathrm{Cr}(\mathrm{VI})$ is highly soluble thus present in large amount and increases the environmental pollution load (Kimbrough et al., 1999). Chromate cause cellular toxicity due to its carcinogenic, mutagenic and teratogenic nature, thus listed as priority pollutant by Environmental Protection Agency (EPA) and World Health Organization (WHO) (Nariagu and Pacyna, 1989; USEPA, 1998). The recommended acceptable limit for $\mathrm{Cr}(\mathrm{VI})$ in potable water and household usage should

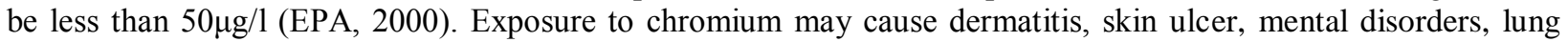
cancer, kidney and liver damage in humans and animals (Cohen et al., 1993). Presence of $\mathrm{Cr}(\mathrm{VI})$ and other metals in 
the soil also effects plant growth due to inhibition of photosynthesis, reduced shoot and root length, decrease in enzyme activity, seed germination rate and total protein content (Narain et al., 2012; Verma and Maurya, 2014). Strategies aimed to detoxify chromate contaminated environment by appropriate methods are therefore urgent.

Several treatment methods such as chemical precipitation, ion exchange, adsorption, chemical oxidation, etc. have been earlier used for the treatment of metal contaminated waste. However, these treatments are very expensive, require large amount of chemical and energy, produce secondary waste into the environment and affect soil texture (Szpyrkowicz et al., 2001; Verma and Singh, 2013). Bacteria show potential approach in this regard as they could adapt and inhabit such polluted environments and remediate the toxic metals by converting them into less toxic and easily disposable forms.

Several bacteria have been reported to bioremediate $\mathrm{Cr}(\mathrm{VI})$ by bioreduction, bioaccumulation, biosorption, enzyme catalysed transformations, use of immobilized cells and enzymes and application of biosurfactants (Srinath et al., 2002; Verma et al., 2009; Panda and Sarkar 2012; Singh et al., 2013; Vijayanand and Divyashree, 2015). However, the simple metabolic activity alone is not efficient for $\mathrm{Cr}(\mathrm{VI})$ remediation especially at highly polluted sites. Thus, use of bacterial detoxification activity along with the bacterial biosurfactants is a promising strategy for Cr(VI) detoxification at higher rate from polluted soil/water. It would increase the efficiency of metal sequestration and thus economically viable and environmentally compatible (AmeerBasha, and Rajaganesh, 2014; Adamu et al., 2015; Govarthanan et al., 2017).

Biosurfactants are surface active compounds that are produced by bacteria, yeasts and fungi either extracellularly or as part of the cell membrane (Juwarkar et al., 2008). They are non-toxic and possess high surface activity and emulsifying activity. Biosurfactants are able to reduce surface and interfacial tension at the interfaces between liquids, solids, and gases, thereby allowing them to mix or disperse readily as emulsions in water or other liquids, thus, can be safely used for heavy metal bioremediation. Hence, the present work was focused to isolate chromate resistant indigenous bacteria from chromium contaminated industrial waste and to investigate its biosurfactant production efficacy in view of $\mathrm{Cr}(\mathrm{VI})$ bioremediation.

\section{Methodology:-}

\section{Media and Chemicals:-}

The media components and reagents used in this study were of analytical grade and procured from Merck, HiMedia, Qualigens, India Ltd. and Sigma Aldrich chemicals, USA. For the determination of hexavalent chromium, diphenylcarbazide (DPC) solution $(0.25 \%$, w/v) was prepared by dissolving $125 \mathrm{mg} 1,5$ - diphenylcarbazide in to 25 $\mathrm{ml}$ of high performance liquid chromatography (HPLC) grade acetone and stored in brown glass bottle.

\section{Sampling and isolation of chromate resistant biosurfactant producing bacteria:-}

The soil sample was collected from the dumping site of battery manufacturing High Flow Industry Private Limited, Faizabad, India in sterile containers, transported on ice to the laboratory and was processed for bacterial isolation within 4-6 h of collection. One gram of soil was serially diluted into saline $(0.6 \% \mathrm{NaCl})$ up to $10^{-7}$ dilution and bacteria were isolated by the standard pour plate technique on nutrient agar plates $(\mathrm{pH} \mathrm{7.5)}$ ammended with varying chromate concentration $\left(100-500 \mu \mathrm{g} / \mathrm{ml}\right.$ ) (APHA, 1998). The plates were incubated at $30 \pm 1^{\circ} \mathrm{C}$ for $24-36 \mathrm{~h}$. Morphologically different bacterial colonies were selected and purified by repeated streaking on selective agar plates to obtain pure isolates.

\section{Analysis of heavy metals in soil sample:-}

The heavy metal concentration present in the chromium contaminated soil was estimated using AAS, after acid digestion of samples with a mixture of concentrated nitric acid:perchloric acid (6:1, v/v) (APHA, 1998). AAS grade metal solutions (Sigma Aldrich Chemicals, USA) were used as standards.

\section{Minimal inhibitory concentration of $\mathrm{Cr}(\mathrm{VI})$ :-}

The minimal inhibitory concentration (MIC) of chromate was determined by the agar dilution method (Verma et al., 2001). The $\log$ phase cultures of the bacterial isolates were inoculated aseptically on nutrient agar plates supplemented with different concentrations of $\mathrm{Cr}(\mathrm{VI})(250-1450 \mu \mathrm{g} / \mathrm{ml})$. Plates were incubated for $24-36 \mathrm{~h}$ at $30 \pm 1{ }^{\circ} \mathrm{C}$. Minimum concentration of $\mathrm{Cr}$ (VI) that completely inhibited growth of bacteria was considered the MIC of that isolate. 


\section{Cr(VI) reduction Assay:-}

The five selected bacterial strains were evaluated for their chromate detoxification ability by reduction of $\mathrm{Cr}(\mathrm{VI})$ to less toxic $\mathrm{Cr}(\mathrm{III})$ at the respective maximum chromate tolerance concentrations. Chromate concentration was determined in the supernatant fraction of overnight grown cultures by diphenylcarbazide (DPC) method at $540 \mathrm{~nm}$ using UV-Vis spectrophotometer by measuring absorbance of the purple complex of $\mathrm{Cr}(\mathrm{VI})$ with 1,5diphenylcarbazide after 6, 12, 18, 24, 28 and $32 \mathrm{~h}$ of growth (APHA 1998), and the $\mathrm{Cr}(\mathrm{VI})$ concentration was determined by the standard curve of $\mathrm{K}_{2} \mathrm{Cr}_{2} \mathrm{O}_{7}(100-1500 \mathrm{mg} / \mathrm{l}$ ) (Maurya and Verma, 2014). Uninoculated $\mathrm{Cr}(\mathrm{VI})$ amended broth served as control. The initial $(0 \mathrm{~h})$ and final (after incubation) $\mathrm{Cr}(\mathrm{VI})$ concentration was determined by the DPC method and the $\mathrm{Cr}(\mathrm{VI})$ reduction efficiency of bacteria is determined in terms of "\% $\mathrm{Cr}(\mathrm{VI})$ reduction". Total $\mathrm{Cr}$ i.e., $\mathrm{Cr}(\mathrm{VI})+\mathrm{Cr}(\mathrm{III})$, in the supernatant was determined by atomic absorption spectrophotometer (AAS) at $357.9 \mathrm{~nm}$, after digesting the supernatant with the mixture of nitric acid and perchloric acid $(6: 1, \mathrm{v} / \mathrm{v})$.

\section{Screening of bacteria for biosurfactant production:-}

Five bacterial isolates exhibiting high MIC values for $\mathrm{Cr}(\mathrm{VI})$ and reducing it to less toxic $\mathrm{Cr}(\mathrm{III})$ were selected to evaluate their biosurfactant production efficiency by following methods:

\section{Methylene Blue Plate Assay:-}

The selected bacteria were screened for biosurfactant production by streaking on minimal salt medium plates ammended with respective chromate concentrations. The medium was supplemented with $200 \mu \mathrm{g} / \mathrm{ml}$ cetyl-trimethyl-ammonium bromide (CTAB; Himedia), $5 \mu \mathrm{g} / \mathrm{ml}$ methylene blue, and 1.5\% agar agar (Satpute et al., 2008). The inoculated plates were incubated at $30 \pm 1^{\circ} \mathrm{C}$ for $24-36 \mathrm{~h}$. The ability of bacteria to form dark blue halo zone around the culture was considered positive for biosurfactant production.

\section{Blood hemolysis test:-}

Overnight grown bacteria were streaked on blood agar plates followed by incubation at $30 \pm 1^{\circ} \mathrm{C}$ for $24 \mathrm{~h}$ and the haemolysis was measured (Satpute et al., 2008). Presence of clear zone (hemolytic activity) around the bacterial colonies indicated the production of biosurfactant by the test strain. The zone appears due to the lyses of red blood cells by the biosurfactant produced.

\section{Emulsification test:-}

This test was performed to measure the stability of biosurfactant and its emulsification ability towards hydrocarbons (sunflower oil, olive oil and kerosene) (Paraszkiewicz et al., 1992). Bacterial colonies were grown in test tubes containing $2 \mathrm{ml}$ of nutrient broth and incubated for $24 \mathrm{~h}$. Thereafter, $2 \mathrm{ml}$ hydrocarbon oil was added to each tube and it was then vortexed at high speed for 2 mins, left to stand for $24 \mathrm{~h}$ and the height of the stable emulsion layer $(\mathrm{mm})$ is measured. The emulsification index $\left(\mathrm{E}_{24}\right)$ was calculated as the percentage of the height of the emulsion layer developed $(\mathrm{mm})$ divided by the total height of liquid medium $(\mathrm{mm})$.

$$
\mathrm{E}_{24}=\frac{\mathrm{H}_{\text {emulsion }}}{--\mathrm{H}_{\text {total }}}
$$

where,

$\mathrm{E}_{24}$ is emulsion index after 24 hours,

$\mathrm{H}_{\text {emulsion }}$ is the height of emulsion layer developed,

$\mathrm{H}_{\text {total }}$ is the total height of the liquid medium

\section{Oil spreading technique:-}

The oil spreading method was followed according to Morikawa et al. (1993). Twenty milliliters of distilled water was taken in a Petri dish and $0.5 \mathrm{ml}$ of kerosene oil was added onto the distilled water surface. Then one drop of the culture supernatant was added on the centre of kerosene oil surface. The biosurfactant producing bacteria displaced the oil and spread in the water. The diameter of the clear zone visualized on the oil surface was measured after 25-40 seconds, which correlates to the surface tension reduction efficiency of the biosurfactant. It is also called as oil displacement activity.

\section{Identification of the selected bacteria:-}

Among the five bacterial isolates, TB9 and TB10 was the most promising isolate in terms of concomitant biosurfactant production and $\mathrm{Cr}(\mathrm{VI})$ reduction efficiency and was identified following the scheme of Cowan and 
Steel (1993). The various biochemical tests were performed and results were interpreted according to Bergey's Manual of Determinative Bacteriology (Holt et al., 1994).

\section{Results and Discussion:-}

\section{Isolation of bacteria and $\mathrm{Cr}$ (VI) MIC Determination:-}

A total of eleven morphologically different bacteria tolerant to varying $\mathrm{Cr}(\mathrm{VI})$ concentration between $250-500 \mu \mathrm{g} / \mathrm{ml}$ were isolated from chromium contaminated soil of battery manufacturing industry. The MIC of $\mathrm{Cr}(\mathrm{VI})$ for these strains was evaluated in order to determine the maximum tolerance limit for hexavalent chromium. The Cr(VI) MIC of these strains ranged between 500-1400 $\mu \mathrm{g} / \mathrm{ml}$ (Fig. 1). Among them, on the basis of higher MIC values, five bacterial strains (TB1, TB5, TB9, TB10 and TB11) were selected for further studies. Their MIC for Cr(VI) was 1100, 1150, 1350, 1400 and $1200 \mu \mathrm{g} / \mathrm{ml}$, respectively. This study highlights the prevalent occurrence of Cr(VI) resistant bacterial population in the soil of dumping site of battery industry waste. It also reveals that continuous exposure to high levels of $\mathrm{Cr}(\mathrm{VI})$ may result in bacterial community that have an exceptional ability to adapt in chromate polluted environments and might have developed some detoxification mechanism as an effective tool for survival in the stress environments (Rehman et al., 2008).

\section{Heavy metal Analysis:-}

The Cr(VI) and total Cr in the soil (mg/kg) of battery industry waste dumping site was $1170 \pm 0.2$ and $2900 \pm 0.09$, respectively, which is much above the permissible limit. Further, the concentration $(\mathrm{mg} / \mathrm{kg})$ of other heavy metals

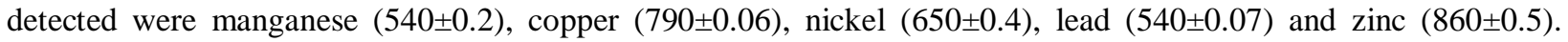
Results revealed that in addition to $\mathrm{Cr}(\mathrm{VI})$, the waste discharged from battery industry contains other metals in significant quantities which are ultimately causing pollution of soil, water bodies and the agricultural lands close to it. Since, large amount of waste is generated everyday from industries; chromium and other metals discharged through their waste into the environment get biomagnified along the trophic level, thus leading to ecotoxicological risk (Armienta et al., 2001). Further, ground water quality is getting deteriorated due to seepage of chromate ions from the waste dumping site (Verma et al., 2004). Results proved that the industrial waste discharged is not properly treated and stresses for its revaluation prior to disposal. The phytotoxic impact of chromium was observed in tomatoes, cabbage, rice, waterchestnut, pulses, etc. as visible symptoms of yellowing and immature fall of leaves, chlorosis, poor growth and retarded flower and fruit yield. This was possibly attributed to imbalance of nutrients and nutritional disorders in the plants due to metal interactions with plant nutrients (Chunillal et al., 2005). Also, entry of toxic $\mathrm{Cr}(\mathrm{VI})$ in the food chain through contaminated edibles may cause health hazards (Sharma et al., 1996). Moreover, $\mathrm{Cr}(\mathrm{VI})$ is non-degradable in nature and are dispersed both horizontally and vertically. Therefore, there is an urgent need for the bioremediation of $\mathrm{Cr}(\mathrm{VI})$ from the waste dumping sites.

\section{Cr(VI) reduction Assay:-}

The $\mathrm{Cr}(\mathrm{VI})$ reduction potential of the selected five bacterial strains was determined and the results are depicted in Figure 2. All the five isolates in this study were capable of reducing $\mathrm{Cr}(\mathrm{VI})$ aerobically and the reduction values ranged between 59.0-90.0\%. Significant reduction was observed in the supernatant fraction of TB10 strain (90.0\%) after $20 \mathrm{~h}$ of growth followed by TB9 (83\%), TB11 (72.0\%) and TB1 (65.0\%) strain. However, the TB5 isolate reduced $\mathrm{Cr}(\mathrm{VI})$ less efficiently. The $\mathrm{Cr}(\mathrm{VI})$ concentration in uninoculated broth (control) remained the same throughout the experiment, indicating that medium components were unable to reduce $\mathrm{Cr}(\mathrm{VI})$ to a lower valency state. Reduction of $\mathrm{Cr}(\mathrm{VI})$ to $\mathrm{Cr}$ (III) has been reported by many bacterial types taking 2-9 days (Ma et al., 2007; Panda and Sarkar, 2012). This prolonged period for chromium removal may lead to accumulation of metal and toxic compounds in the environment. The effective removal of chromium in a short time is a basic necessity of the present time. Since, strain TB9, 10 and 11 reduced $72-90 \% \mathrm{Cr}(\mathrm{VI})$ in $\sim 20 \mathrm{~h}$, it may definitely improve the efficiency of the treatment of chromate contaminated wastes.

\section{Screening of bacteria for biosurfactant production:-}

The five bacteria selected on the basis of high $\mathrm{Cr}(\mathrm{VI}) \mathrm{MIC}$ values, were screened for their ability to produce biosurfactant following the standard qualitative and quantitative tests and the results are presented in Table 1. Appearance of dark blue halo zone around the culture of all bacterial isolates except TB5 strain on CTAB-MB MSM agar indicated the production of anionic biosurfactant by bacteria. The ability of biosurfactant producing bacteria to form clear halos in methylene blue agar plate assay has also been reported by other researchers (Adamu et al., 2015; Vijayanand and Divyashree, 2015; Okore et al., 2017). Blood hemolysis test is used to screen the microbes for their ability to produce biosurfactants on hydrophilic media. Table 1 revealed that bacterial strains TB5, TB9 and TB10 showed positive results for beta haemolysis on blood agar medium, thereby, indicating production of surface active 
molecules (biosurfactant) which causes lyses of red blood cells. Vijayanand and Divyashree (2015) and Okore et al. (2017) have demonstrated the hemolytic activity of Bacillus, Citrobacter, Pseudomonas, Staphylococcus, Corynebacterim and other bacterial species on blood agar. Hemolytic activity has been regarded as indicative of biosurfactant production and used as a rapid method for bacterial screening (Satpute et al., 2008).

The quantitative tests for biosurfactant production comprises of emulsification capacity test and oil spreading method. Results for emulsification of hydrocarbon revealed that bacterial strains TB9, TB10 and TB11 emulsified sunflower oil, olive oil and kerosene at varying rates and were also hemolytic (Table 1). This proves that these isolates are capable to produce biosurfactant which has ability to degrade hydrocarbon. Further, strain TB1 could emulsify sunflower oil and kerosene at very low rate. Among the three isolates, interestingly TB9 showed highest emulsification index $\left(\mathrm{E}_{24}\right)$ after 24 hours of incubation for sunflower oil $(74 \pm 1.60)$ followed by kerosene (72 \pm 0.5$)$ and olive oil $(65 \pm 0.3)$, whereas, strain TB10 showed highest $\mathrm{E}_{24}$ value for olive oil (74 \pm 1.2$)$ followed by sunflower oil (70 \pm 0.29$)$ and kerosene $(68 \pm 0.19)$ after the same period of exposure. However, the $E_{24}$ values of TB11 strain was significantly lower for all the three hydrocarbons tested. Further, all the isolates that were hemolytic were also able to emulsify the hydrocarbons tested except the strain TB5. The inability of TB5 to emulsify the oil indicated its failure to produce biosurfactant and hence, the hemolytic activity could be attributed to extracellular secretions. Similar findings were reported by Adamu et al., (2015) and Govarthanan et al., (2017). Results for oil spreading test (Table 1) of the kerosene oil revealed that strain TB9 and TB10 caused the spreading of the oil at the rate of 6 and 5 minutes with a diameter of $2.7 \mathrm{~cm}$ and $3.3 \mathrm{~cm}$, respectively. Results also showed that the TB11 strain showed positive results for hemolysis and emulsification but was unable to spread the oil. This might be because some bacteria do not produce extracellular material as biosurfactant but the cells itself acts as biosurfactant (Adamu et al., 2015).

\section{Bacterial Identification:-}

Based on the results of concomitant biosurfactant production efficiency and chromate reduction potential, bacterial strains TB9 and TB10 seems to be most efficient strains that can be potentially be used for Cr(VI) bioremediation and environmental restoration. Thus, both strains were chosen for detailed study on optimization of biosurfactant production and chromate removal applications. On the basis of morphological and biochemical characteristics both the strains were identified as Pseudomonas aeruginosa and Bacillus cereus, respectively (Table 2).

Table1:-Screening of bacteria for biosurfactant production

\begin{tabular}{|c|c|c|c|c|c|c|c|}
\hline \multirow{2}{*}{$\begin{array}{c}\text { Bacterial } \\
\text { isolates }\end{array}$} & \multirow{2}{*}{$\begin{array}{c}\text { Methylene } \\
\text { Blue Plate } \\
\text { Assay }\end{array}$} & \multirow{2}{*}{$\begin{array}{c}\text { Hemolysis } \\
\text { test }\end{array}$} & \multicolumn{3}{|c|}{ Emulsification index $\mathrm{E}_{24}(\%)$} & \multicolumn{2}{|c|}{ Oil displacement } \\
\hline & & & $\begin{array}{c}\text { Sunflower } \\
\text { oil }\end{array}$ & Olive oil & Kerosene & $\begin{array}{c}\text { Diameter } \\
(\mathrm{cm})\end{array}$ & $\begin{array}{l}\text { Time } \\
(\mathrm{min})\end{array}$ \\
\hline TB1 & + & - & $20 \pm 0.72$ & - & $23 \pm 0.28$ & - & - \\
\hline TB5 & - & + & - & - & - & - & - \\
\hline TB9 & + & + & $74 \pm 1.60$ & $65 \pm 0.3$ & $72 \pm 0.5$ & 2.7 & 6 \\
\hline TB10 & + & + & $70 \pm 0.29$ & $74 \pm 1.2$ & $68 \pm 0.19$ & 3.3 & 5 \\
\hline TB11 & + & + & $19 \pm 1.0$ & $36 \pm 0.5$ & $24 \pm 1.2$ & - & - \\
\hline
\end{tabular}

(+) Positive, (-) negative

Table 2:-Morphological and biochemical characteristics of selected TB9 and TB10 isolate.

\begin{tabular}{|l|l|l|}
\hline \multicolumn{1}{|c|}{ Characteristics } & \multicolumn{2}{c|}{ TB9 } \\
\cline { 2 - 3 } & \multicolumn{1}{|c|}{ Bacterial strain } \\
\hline Colony Morphology & $\begin{array}{l}\text { Bluish-green, raised, non-mucoid, } \\
\text { circular colonies with smooth margin }\end{array}$ & $\begin{array}{l}\text { Cream, raised, non-mucoid, } \\
\text { circular colonies with serrated } \\
\text { margin }\end{array}$ \\
\hline Gram reaction & Gram negative, rod & Gram positive, rod \\
\hline Endospore formation & - & + (central) \\
\hline Indole test & + & - \\
\hline Methyl Red test & - & + \\
\hline VogesProsekaeur & + & - \\
\hline Citrate utilization & - & + \\
\hline Casien hydrolysis & - & + \\
\hline Starch hydrolysis & - & + \\
\hline
\end{tabular}




\begin{tabular}{|l|l|l|}
\hline Urea hydrolysis & - & + \\
\hline Gelatin hydrolysis & - & + \\
\hline Catalase test & - & + \\
\hline Oxidase test & + & + \\
\hline Nitrate reduction & + & - \\
\hline $\mathrm{H}_{2}$ S production & - & - \\
\hline Cytochrome oxidase test & + & - \\
\hline Acid production from carbohydrates & \multicolumn{2}{|l|}{} \\
\hline Glucose & + & + \\
\hline Lactose & - & - \\
\hline Fructose & + & + \\
\hline Sucrose & - & + \\
\hline Arabinose & + & - \\
\hline Possible bacterial strain & Pseudomonas aeruginosa & Bacillus cereus \\
\hline
\end{tabular}

(+) Positive, (-) negative

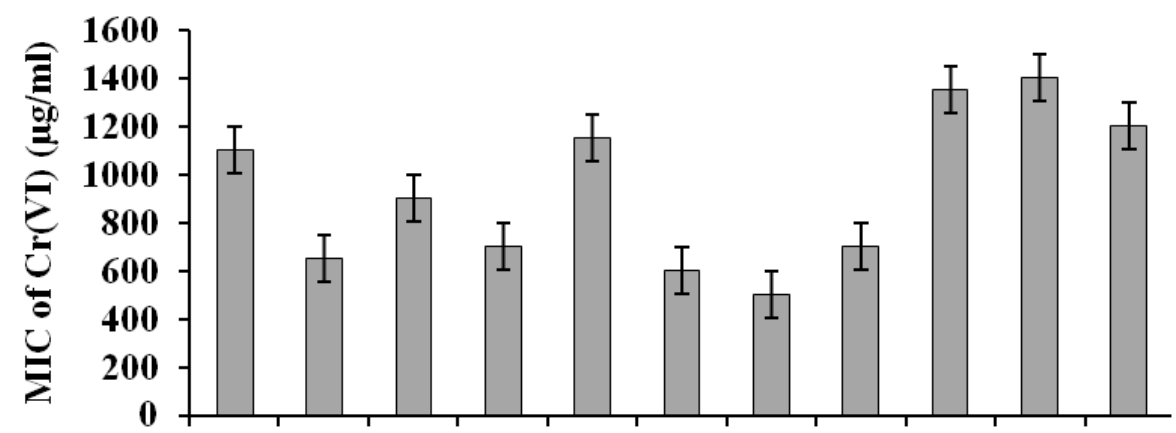

TB1 TB2 TB3 TB4 TB5 TB6 TB7 TB8 TB9 TB10TB11

Bacterial Strains

Figure 1:- Minimum inhibitory concentration for $\mathrm{Cr}(\mathrm{VI})$ by chromate tolerant bacterial strains. Error bars represent mean \pm standard deviation.

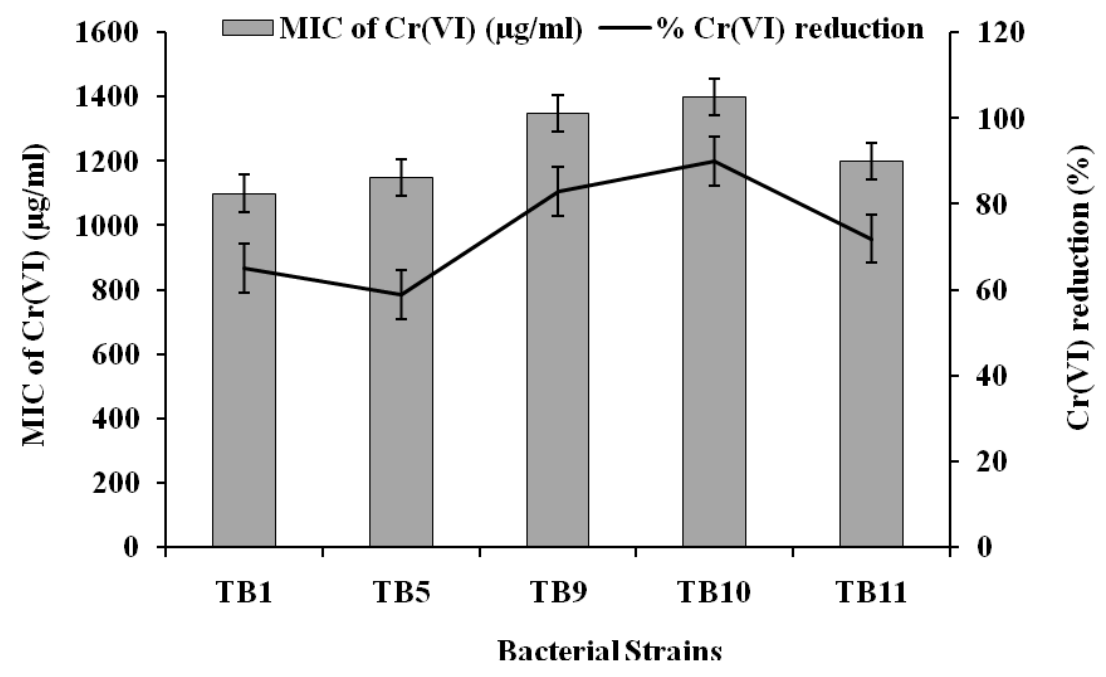

Figure 2:- Chromate reduction potential and the respective $\mathrm{MIC}$ for $\mathrm{Cr}(\mathrm{VI})$ among selected bacterial strains. Error bars represent mean \pm standard deviation. 


\section{Conclusion:-}

Metal contamination of soil due to disposal of industrial waste has increased considerably in recent years leading to contamination of the environmental reservoirs such as water bodies and soils. Soil usually acts as a sink for harboring metals. These metals being immobile in soil accumulate and influence the properties of soil adversely. A novel approach for enhanced bioremediation of metal contaminated site is the use of microbial surfactants. The present study focuses on the biosurfactant production by chromate tolerant Pseudomonas aeruginosa and Bacillus cereus and assessing their potential for bioremediation of chromate from contaminated site. The bacteria of this study offers an interesting model for further studies, as well as an alternative to be exploited for $\operatorname{Cr}(\mathrm{VI})$ bioremediation in a wide range of environments.

\section{References:-}

1. Adamu, A., Ijah, A.J.J., Riskuwa, M.L., Ismail, H.Y. and Ibrahim, U.B. (2015): Isolation of biosurfactant producing bacteria from tannery effluents in Sokoto Metropolis, Nigeria. Int. J. of Inn. Sci. Eng. Technol., 2: 366-373.

2. Ameerbasha, S. and Rajaganesh, K. (2014): Microbial bioremediation of heavy metals from textile industry dye effluents using isolated bacterial strains. Int. J. Curr. Microbiol. Appl. Sci., 3 (5): 785-794.

3. APHA, (1998): Standard Methods for the Examination of Water and Wastewater. American Public Health Association, 20th Edn., APHA Press, Washington, DC.

4. Armienta, M.A., Morton, O., Rodriguez, R., Cruz, O., Aguayo, A. and Ceniceros, N. (2001): Chromium in a tannery wastewater irrigated area, Leon Valley, Mexico. Bull. Environ. Contam. Toxicol., 66: 189-195.

5. Chunillal, V., Kindness, A., and Jonnaladda, S.B. (2005): Heavy metal uptake by two edible Ammaranthus herbs grown on soil contaminated with lead, mercury, cadmium and nickel. J. Env. Sci. Health, 40: $375-384$.

6. Cohen, M.D., Kargacin, B., Klein, C.B. and Costa, M. (1993): Mechanism of chromium carcinogenicity and toxicity. Crit. Rev. Toxicol., 23: 255-281.

7. Cowan, S. T. and Steel, K.J. (1993): Manual for the Identification of Medical Bacteria. 3rd Edn. University Press, Cambridge, pp. 6-41.

8. Environmental Protection Agency (EPA) (2000): List of Drinking water contaminants and MCL's. [http://www.epa.gov.ogwdw/mcl/html] EPA, 816-6-02-013.

9. Govarthanan, M., Mythili, R., Selvankumar, T., Kannan, S.K., Choi, D. and Chang, Y.C. (2017): Isolation and characterization of biosurfactant-producing heavy metal resistant Rahnella sp. RM isolated from chromiumcontaminated soil. Biotechnol. Bioprocess Eng., 22: 186-194.

10. Holt, J.G., Kreig, N.R., Sneath, P.H.A., Staley, J.T. and Williams, S.T. (1994): Bergey's Manual of Determinative Bacteriology. Williams and Wilkins, Baltimore, pp. 787.

11. Juwarkar, A.A., Dubey, K.V., Nair, A. and Singh, S.K. (2008): Bioremediation of multi-metal contaminated soil using biosurfactant- a novel approach. Ind. J. Microbiol., 48: 142-146.

12. Kimbrough, D.E., Cohen, Y., Winer, A.M., Creelman, L. and Mabuni, C. (1999): A critical assessment of chromium in the environment. CRC Crt. Rev. Environ. Sci. Technol., 29: 1-46.

13. Ma, Z., Zhu, W., Long, H., Chai, L. and Wang, Q. (2007) Chromate reduction by resting cells of Achromobactersp. Ch-1 under aerobic conditions. Process Biochem. 42, 1028-1032.

14. Maurya, A. and Verma, T. (2014): Concomitant bioremediation of chromium (VI) and pentachlorophenol from the tannery effluent by immobilized Brevibacteriumcasei. IOSR J. Eng., 4: 29-39.

15. Morikawa, M., Daido, H., Takao, T., Marato, S., Shimonishi, Y. and Imanaka, T. (1993): A new lipopeptidebiosurfactant produced by Arthrobacter sp. strain MIS 38. J. Bacteriol., 175: 6459-6466.

16. Narain, K., Bhat, M.M., Abhilash, P.C., Yunus, M. (2012): Impact of distillery effluent on seedling growth and pigment concentration of Cicerarietinum L. J. Environ. Res. Develop., 6: 601-608.

17. Nariagu, J.O. and Pacyna, J.M. (1989): Quantitative assessment of worldwide contamination of air, water and soil by trace metals. Nature, 333: 134-139.

18. Okore, C.C., Nwaehiri, L.U., Mbanefo, O.N., Ogbulie, T.E., Ugenyi, A.U., Ogbuka, I.B. and Ejele, A.E. (2017): Study on microbial diversity of biosurfactant producing from contaminated environmental samples. Int. J. Adv. Res., 5: 1387-1396.

19. Panda, J. and Sarkar, P. (2012): Bioremediation of chromium by novel strains Enterobacteraerogenes T2 and Acinetobacter sp. PD 12 S2. Environ. Sci. Pollut. Res. Int., 19: 1809-1817.

20. Paraszkiewicz, K., Kanwal, A. and Dlugonski, J. (1992): Emulsifier production by steroid transforming filamentous fungus Curvularialunata, growth and product characterization. J. Biotechnol., 92: 287-294. 
21. Rehman, A., Zahoor, A., Muneer, B. and Hasnain, S. (2008): Chromium tolerance and reduction potential of Bacillus sp.ev3 isolated from metal contaminated wastewaster. Bull. Environ. Contam. Toxicol., 81: 25-29.

22. Satpute, S.K., Bhawsar, B.D., Dhakephalkar, P.K. and Chopade, B.A. (2008): Assessment of different screening methods for selecting biosurfactant producing marine bacteria. Ind. J. Mar. Sci., 37: 243-250.

23. Sharma, D.C., Srivastava, P.C., Johri, B.N., and Chandra, P. (1996). Environmental impact of tannery effluents on heavy metal phytotoxicity and health hazards. Poll. Res., 15: 267-269.

24. Singh, N., Verma, T. and Gaur, R. (2013): Detoxification of hexavalent chromium by an indigenous facultative anaerobic Bacillus cereus strain isolated from tannery effluent. Afr. J. Biotechnol., 12: 1091-1103.

25. Srinath, T., Verma, T., Ramteke, P.W. and Garg, S.K. (2002): Chromium (VI) biosorption and bioaccumulation by chromate resistant bacteria. Chemosphere, 48: 427-435.

26. Szpyrkowicz, L., Jelsall, G.H., Kaul, S.N. and Faveri, M.D. (2001): Performance of electrochemical reactor for treatment of tannery wastewaters. Chem. Eng. Sci., 56:1579-1586.

27. USEPA (1998): Toxicological Review of Hexavalent Chromium. CAS No. 18540-29-9. Washington, DC, U.S. Environmental Protection Agency.

28. Verma, T. and Singh, N. (2013): Isolation and process parameter optimization of Brevibacteriumcasei for simultaneous bioremediation of hexavalent chromium and pentachlorophenol. J. Basic Microbiol., 53: 277-290.

29. Verma, T., and Maurya, A. (2014): Effect of bacterial treated and raw tannery effluent on seed germination and growth parameters of black gram (VignamungoL.). In: Rao RK, Sharma PK and Singh AK (eds) Novel Innovations and Strategies for Boosting Production and Productivity in Agriculture: Mahima Research Foundation and Social Welfare, Varanasi, India publication, ISBN: 978-81-926935-4-5, pp. 168-178.

30. Verma, T., Ramteke, P.W. and Garg, S.K. (2004): Occurrence of chromium resistant thermotolerant coliforms in tannery effluent. Indian J. Exp. Biol., 42: 1112-1116.

31. Verma, T., Srinath, T., Gadpayle, R., Ramteke, P.W., Hans, R.K. and Garg, S.K. (2001): Chromate tolerant bacteria isolated from tannery effluents. Biores. Technol., 78: 31-35.

32. Verma, T., Garg, S.K. and Ramteke, P.W. (2009): Genetic correlation between chromium resistance and reduction in Bacillus brevis isolated from tannery effluent. J. Appl. Microbiol., 107: 1425-1432.

33. Vijayanand, S. and Divyashree, M. (2015): Bioremediation of heavy metals using biosurfactant producing microorganisms. Int. J. Pharma. Sci. Res., 6: 840-847. 